\title{
Export Market Orientation for Manufacturing Small- Medium Enterprises in East Java Indonesia
}

\author{
A. Yahya Surya Winata ${ }^{1}$ Student of Doctoral Program in Management Science, Padjadjaran University, Jalan Dipati Ukur No. \\ 25 Bandung, 40131, Indonesia ${ }^{1}$ Lecturer of Management Studies, Economic \& Business Faculty, Universitas Trunojoyo Madura, \\ Jalan Raya Telang PO BOX 2 Kamal-Bangkalan, 69162, Indonesia \\ Email: yahyasuryawinata@gmail.com
}

\begin{abstract}
The best value creation for customers is a key to be able to achieve the survival and best performance of business in the long run. It can only be achieved if a business organization has a market orientation. Export market orientation according to some authors also referred to as advanced of market orientation is generally only be done by large companies. However, in this study tried to describe the implementation of the export market orientation in manufacturing SMEs East Java Province in Indonesia, and then determine how far the level export market orientation descriptively using five Sturges criteria.

Indicators of export market orientation refers to indicators developed by many authors with modifications in the context of SMEs in East Java. Sampling study conducted on 200 SME Manufacturing in East Java which has been exporting for at least the past three years.

The results showed that in general the export market orientation Manufacturing SMEs in East Java is at a level of 3.15 on Sturges criteria, indicating that the export market orientation of manufacturing SMEs in East Java in general are quite good criteria. The results of these studies indicate that SMEs are generally able to implement an expanded concept of market orientation in the international environment.
\end{abstract}

Keywords; export market orientation, manufacturing SMEs, East Java SME's

\section{INTRODUCTION}

Most countries in the world obtain a source of national income in order to increase foreign exchange earnings through exporting. For Indonesia, non-oil products has become a priority in the export trade to foreign countries for many years. The percentage of non-oil exports in Indonesia is still dominated by large corporations, and only $16.44 \%$ of the total Indonesian exports contributed by small and medium enterprises (SMEs). Its smallest contribution compared to some countries in Asia, as the results of previous research [1] showed that exports of manufacturing SMEs in Taiwan contribute to the country's total exports by $56 \%$, China and Korea for more than $40 \%$, and India $31 \%$.

At least there are two factors that lead the low of SMEs export performance so that lower the value of its contribution to the total national exports [2]. Both of these obstacles are internal and external constraints. The internal constraints related to access with information about foreign markets, functional ability/managerial facing foreign markets, and marketing. While external factors associated with export procedures, the role of government, the difficulties facing foreign competitors and customers, and the differences in the economic, political, and social culture [2],[3].

However attractiveness of overseas markets remain to be penetrated by SMEs. Reference [3] illustrates that many small businesses do not care about their weaknesses then deal directly with their competitors with more global business perspective by entering the international market. Facing foreign business environment requires a lot of information about customer's need and want, and some of the factors that could affect customer preferences shift. Those can be achieved when SMEs have a strong export market orientation.

Export market orientation is the advance level of the market orientation basic concept that implement for export market [4]. The study of market orientation generally implement in large enterprises. The large enterprises however has the advantage of economies of scale, bargaining power of suppliers and distributors, the brand that has been known, experience curve effects, monopolistic powers to determine the price below the market price, as well as access to resources [5]. While SMEs have different characteristics than large firms, such as: the business is run and controlled under the supervision of a person that is the owner of the SME [6]; self-directed, work-based dan informal-learning [7]; less excel in product categories, defensive when the business environment changes, even more open to resign if better opportunities [8].

Therefore, this study was conducted to assess the export market orientation practices in manufacturing SMEs in East Java province that was already exporting to several countries and then determine degree of export market orientation of the SME. 


\section{THEORETICAL REVIEW}

\section{A. Market Orientation}

Market orientation is a foundation and the central concept of the marketing discipline [9], and examined on some literature, studies of the market orientation concept is generally developed from the concept of a marketing strategy [10]. The definition of market orientation developed Kohli and Jaworski, also Narver and Slater until now generally still relevant so as to be used as the basis of the development of a definition by the researchers in conducting studies in different fields.

Based on the review of the literature, market orientation can be classified into three approaches are:

\section{a). Behavioral approach}

As reference [11] states that "a concept developed by Kohli and Jaworski is a behavioral approach to the concept of market orientation". It refers to the three activities related to the search of information about the needs of consumers both visible and latent through market intelligence, further disseminate the information obtained to the entire member of organization, and finally formulate a strategy as a form all members' response to the information obtained through creating value offer to the consumers.

Behavioral approach is also adopted by reference [12] in the form of strategy implementation ability to lead and manage the behavior of employees collectively. Furthermore, the ability to align the behavior in a competitive context is the key to business performance. Next in the context of export markets, reference [13] showed that the export marketoriented behavior is the key to business success in foreign markets. The behavior of the export market is the company's efforts in collecting in-formation through export market intelligence, disseminate the information to all departments, and determine the action to respond such information.

\section{b) Cultural Approach}

As reference [14] argues that the market orientation is an effective organizational culture in creating and efficient best value for buyers, so as to create the best performance on an ongoing basis for business. Through a cultural approach, [14] developed a model that considers the market orientation as a company culture that is characterized by three components of behavior, i.e., customer orientation, competitor orientation and inter-functional coordination, and two decision criteria, i.e. long-term focus and profit as a target.
Completing the study, the next [15] define market orientation as the ability and the main foundation for culture and organizational learning, because market orientation aims to achieve long-term organizational performance. Organization that has a market-oriented culture is constantly looking for information about customers and competitors. Useful for the development of organizational memory is the basis for organizational learning, also encourages a culture of continuous experimentation in improving organizational processes and systems.

Then reference [16] also agreed that market orientation is an organizational culture that seeks to fine tune the customer as the main thing in business planning. Market orientation according to [16] deals with the translation of knowledge about the market becoming a strategic capabilities (competencies) and then disseminated to members of the organization as a whole, involving the perspective from inside to outside (outward), has a significant correlation with how companies try to align and adapt itself to the needs of today's market as the tendency of changes in customer demand, technology or market shift. Furthermore, business performance can be achieved through the development of a set of systems and processes that are carefully selected, and collectively describe a context that allows the development of capabilities (me-ta-capability) on extraordinary ability (ambidexterity) which continues to grow.

\section{c) Meta-analytic Approach}

The conceptualization of market orientation are ar-ranged in a cultural perspective as well behavior [17]. Through this second perspective, market orientation is placed as a business philosophy that focuses on the customer/client, the advantages, the integration between departments in the organization of the company, to developt good relations between labor, good relations with distributors, and suppliers. Business philosophy can be meaningful as the fundamental philosophy upheld by all members in the organization (mind-set), and will affect behavior and tactical strategically [18]. So the market orientation shows how to think over the inside of the company and how they behave both internally and externally, which is directed by a variety of factors that determine behavior in the market and its behavior towards their customers. A market-oriented organization that has the ability to anticipate, react, and benefit from changes in the environment, so as to direct the best performance [19].

Both [18] and [19] also argues that there are some things that cause a market-oriented organization (antecedent of $\mathrm{MO}$ ) as well as the consequences they pose (consequence of MO). Somewhat different approach was developed further by [20] which defines the orientation of the market as a process of change that occurs in an organization as a whole, by designing a holistic approach. 


\section{B. Market Orientation in Export Environment}

At refference [5] proposed a conceptual framework of market orientation in SMEs by combining two concepts developed by Kohli and Jaworski and Narver and Slater earlier to four dimensions consisting of three dimensions adopted the idea Narver and Slater, and 1 the dimensions of Kohli and Jaworski. The four dimensions are: (1) cus-tomer orientation; (2) competitor orientation, (3) respon-siveness; and (4) coordination among functions. The four dimensions were identified as having two antecedents, among others: (1) organizational structure, which consists of: formalization, centralization, and departmentation; and (2) the culture of the organization, which consists of: learning organization, focusing on the market, entrepre-neurial tendencies, and the context of quality.

Export market orientation (EMO) is the application of market-oriented strategy on export environment [4]. This definition reflects that the export market orientation is the development of the concept of market orientation in the context of the export environment. Another authors such as [21] define market orientation as activities include the creation of market intelligence that can be applied in the company's operations on the export market, distribute knowledge effectively to make judgments that are useful for the design and implementation of strategies to re-spond to the needs of consumers in the export market. Other terms have similar meanings but called by [9] as the International Market Orientation, and is defined as the development of a coordinated behavior between the various functions of the organization which is dedicated to finding and obtaining information about customers, competitors and the overall environment in the interna-tional market destination. The information is then disseminated to all parts of the organization that is com-posed of a response which is then implemented in ac-cordance with the information obtained.

Conceptualization of EMO according [10] consists of three components, namely the behavior of the search for information through intelligence activities export (export generating intelligence), spread as intelligence information obtained through exports to all parts of the company (export disseminating intelligence), and responsiveness on intelligence information obtained through exports (export intelligence responsiveness). These three components are similar to the constructs developed Kohli and Jaworski in the formulation of market orientation, but more specifi-cally in the export frame. The third component also de-scribes the behavior of an organization into a custom-er-oriented, competitors and export environment.

Adaptation of market orientation in the export mar-ket also developed by [9] are construct by three-dimensional measurement of the construct EMO, among others: (1) search for information through the export of intelligence activities, measured by five indica-tors, including the company's activities in creating intelligence about customers, competitors, technology, and other environmental changes; (2) disseminate intelligence information obtained through exports to all parts of the company, has five indicators which contains assessment of the operation in disseminating information obtained from the export market intelligence to the entire staff; and (3) the responsiveness on intelligence export contains three indicators that reflect the company's ability to de-sign and responding to intelligence information obtained. Indicators developed Murray was also adopted by [22] in preparing the export market orientation construct variables to 11 (eleven) item indicators are summarized in three dimensions: (1) market intelligence generation, con-sisting of four items indicators; (2) market intelligence dissemination, consisting of four items indicators; and (3) market intelligence responsiveness, consisting of three items indicators.

\section{Small-Medium Enterprises in Indonesia}

SMEs in Indonesia are grouped into three categories, namely: (1) micro-sized enterprises; (2) small-sized enterprises; and (3) medium-sized enterprises. Classification into three groups, generally based on the amount of labor, the value of the investment, the level of sales or turnover, and the value of assets. Similarly, the definition of SMEs in Indonesia refers to Law No. 20 of 2008 on SMEs, as follows:

(1) Micro-sized enterprises are businesses that have a net worth of Rp 50 million, excluding land and buildings; or having annual sales of Rp 300 million;

(2) Small-sized enterprises is a business that has a net worth> Rp 50 million - Rp 500 million, excluding land and buildings; or have annual sales revenue more than Rp 300 million - Rp 2.5 billion; and

(3) Medium-sized enterprises is a business that has a net worth more than Rp 500 million - Rp 10 billion, excluding land and buildings; or have annual sales revenue more than $\mathrm{Rp}$ 2.5 billion - Rp 50 billion.

Criteria as outlined in the legislation is complemented by the Central Statistics Agency (BPS) in accordance publication, distinguishes four types of manufacturing and grouped by number of employees, namely: large industry (100 employees or more), the industry is / medium (20-99 workers), small industries (5-19 workers), and industrial micro (1-4 workers) [23]. Referring to criteria SMEs as used BPS, and in accordance with the unit of analysis in this study, the SME category can be defined as follows: (1) small enterprises is a business which has a workforce of 5-19 people; and (2) medium enterprises is a business that has a workforce of 20-99 people.

\section{MethodOLOGY}

The data was collected through surveys conducted on the local manufacturing-based SMEs. Structured questionnaire was used as the research instrument. The questionnaire was developed based on reference [9] was also adopted by reference [22] in preparing the export market orientation construct consist 11 item indicators are summarized in three dimensions: (1) market intelligence generation; (2) market intelligence dissemination; and (3) market intelligence responsiveness.

Field investigations are done on the local manufacturebased entrepreneurs using listing of entrepreneurs compiled from the Department of Cooperatives and Micro-Small- 
Medium Enterprises, the province of East Java. The respondents were entrepreneurs who own a registered company and produce manufacture-based products and doing export until this research conducted. From a total of 336 questionnaires distributed, 200 usable questionnaires were collected and analyzed.

Descriptive analysis can be done through the preparation of a frequency distribution table and calculation of descriptive statistics such as the average score. Further-more, to facilitate the interpretation of the score, created a frequency distribution table by first categorizing organizational scores into five categories of answers with Sturges criteria as shown in the following table.

TABLE I. SCORES RANGE \& CATEGORY OF EXPORT MARKET ORIENTATION

\begin{tabular}{|c|c|}
\hline Scores Range & Categories \\
\hline $1-1.79$ & Very weak \\
\hline $1.8-2.59$ & Weak \\
\hline $2.6-3.39$ & Fairly Strong \\
\hline $3.4-4.19$ & Strong \\
\hline $4.2-5$ & Very Strong \\
\hline
\end{tabular}

\section{FINDINGS}

Market-oriented business people are always trying to find information about changing in the market environment, both information related to the general business trend, consumer preferences, the desired target market, as well as competitor activity that can threaten the existence of the company's products in the market. Such information is important to them as a basis for consideration in formulating a business strategy that is used to further improve the performance of the business in the future. Moreover, customers are customers that they face the international market, then they need the export market orientation. To determine the extent of the export market orientation manufacturing SMEs in East Java, descriptive analysis are summarized in Table 2.

Activeness of manufacturing SMEs in East Java to obtain information about the international market environment or general information including the export market indicate fairly active. It shows that in general, they have not worked actively in obtaining information about foreign markets. Active efforts in obtaining information about export markets illustrates how the efforts of SMEs to obtain information relating to the needs and preferences of customers in a country, including the factors that influence the changing needs and preferences of the customer such as a tendency in the business environment that is growing at a state and competitor activity. The more active efforts made to obtain information on export markets through a variety of sources that can be accessed, the more information can be obtained so as to further enrich the knowledge of SMEs on the export market conditions.

Activeness of manufacturing SMEs in East Java to seek information on emerging environmental trends in export destinations including somewhat active (3.33). This shows that they have not been actively especially proactively seek information about the trends of international market environment.
TABLE 2. EXPORT MARKET ORIENTATION OF MANUFACTURING SMES IN EAST JAVA $(n=200)$

\begin{tabular}{|c|l|c|l|l|}
\hline No & \multicolumn{1}{|c|}{ Indicators } & Scores & Categories \\
\hline A & \multicolumn{2}{|c|}{ Export Intelligence Generation } \\
\hline 1 & $\begin{array}{l}\text { Activeness seek information about } \\
\text { foreign environmental trends }\end{array}$ & 3.33 & Fairly \\
\hline 2 & $\begin{array}{l}\text { Activeness seek information about } \\
\text { foreign customer preference }\end{array}$ & 3.21 & Fairly \\
\hline 3 & $\begin{array}{l}\text { Activeness seek information about } \\
\text { foreign target market }\end{array}$ & 3.06 & Fairly \\
\hline 4 & $\begin{array}{l}\text { Activeness seek information about } \\
\text { competitors activity }\end{array}$ & 2.94 & Fairly \\
\hline B & \multicolumn{3}{|c|}{ Export Intelligence Dissemination } \\
\hline 5 & $\begin{array}{l}\text { Speed of deliver information about the } \\
\text { raw materials quality to suppliers }\end{array}$ & 3.72 & Good \\
\hline 6 & $\begin{array}{l}\text { Speed of deliver information about the } \\
\text { product specification to distributors }\end{array}$ & 3.25 & Fairly \\
\hline 7 & $\begin{array}{l}\text { Speed of deliver information about how } \\
\text { to handle products to distributors }\end{array}$ & 3.08 & Fairly \\
\hline 8 & $\begin{array}{l}\text { Speed of deliver information about the } \\
\text { quality of export products to the } \\
\text { production }\end{array}$ & 3.42 & Good \\
\hline C & \multicolumn{2}{|c|}{ Export Intelligence Responsiveness } \\
\hline 9 & $\begin{array}{l}\text { Speed of response to changes in export } \\
\text { business environment }\end{array}$ & 3.14 & Fairly \\
\hline 10 & $\begin{array}{l}\text { Speed of response to competitors price } \\
\text { changes in export market }\end{array}$ & 2.77 & Fairly \\
\hline 11 & $\begin{array}{l}\text { Speed of response to competitive action } \\
\text { that threaten export target market }\end{array}$ & 2.73 & Fairly \\
\hline
\end{tabular}

Furthermore, efforts to seek information about customer preferences also includes somewhat active (3.21). This shows that SMEs have not been actively seek in-formation about the preferences of their customers abroad for information about customer preferences only available from the distributor on the design of the products ordered by customers abroad.

Manufacturing SMEs in East Java also rather actively seek information about their target market (3.06). In such conditions it can be said that SMEs have not been actively seeking information about their target market. Most countries export destination is the target market is currently driven by the demands of foreign tourist's visiting Indonesia, Indonesian workers who work in several countries, and the promotion of SMEs conducted by the government facilitated through participation in international trade fairs.

Efforts to find information about the activities of competitors including somewhat active (2.94). This suggests that SMEs assembly in East Java has not optimize their efforts to be more proactive seek information about the activities of competitors that could threaten the existence of their products in the market. SMEs will be actively looking for information about the activities of their competitors when facing conditions of the decline in sales or customer switch to buy a competitor's product.

In the aspect of dissemination of this export market, the rate of manufacturing SMEs in East Java in conveying information about the quality of raw materials to suppliers are fast (3.72). These conditions indicate that when they obtained information about the change in demand for the product on the export market, the information immediately deliver to supplier for 
inform related changes in the demand for raw materials quality supplied by suppliers.

Speed of deliver information about the quality of the products that customers want to part production export markets, also including fast (3.42). It also shows that SMEs can quickly disseminate or deliver information to the export market parts involved in the company. The rapid delivery of information about export markets to all parts involved in the company, in turn, also showed rapid common understanding in meeting customer wishes.

The submission of information to the dealer on product specifications and on the handling of products including a rather fast (3.25) and (3.08). Both of these indicate that the information about the product cannot be delivered quickly to the distributors. Yet the rapid delivery of in-formation about the product to the dealer indicates constraints experienced in the process of communication between SMEs and distributors. Some SMEs admit that when products are sold through distributors, information on product specifications and how to handle the details are not fully delivered.

Information about changes in the business environment and dissemination can be used as a basis for deter-mining the action more quickly so that SMEs also retains its presence in the international market. Responsiveness on market information into its own problems for SMEs in East Java, because the general level of responsiveness they still include rather quickly. Price adjustment in response changes in price as competitors also not an easy thing to do. This is reflected in the rate of SMEs respond to changes in the price of competitors, including a rather fast (2.77). Such conditions indicate that SMEs in East Java assembly does not yet have a quick responsiveness in response to changes in prices made competitors.

Other reactions in response to competitive actions that threaten the target market also includes a bit faster (2.73). This condition can be interpreted that SMEs in East Java assembly did not immediately respond when there is a competitor actions that threaten their target market. Some SMEs also stated if they experience this condition as well, what they can do is make improvements on certain features of the products they produce, as well as seek to further strengthen its relationship with distributors in order to maintain the market today.

\section{CONCLUSIONS}

According to the sample of respondents, $33 \%$ manufacturing SMEs in East Java have weak export market orientation, 32\% have strong their export market orientation, and $14 \%$ have very strong export market orientation.

The analyses from these companies were also con-ducted to provide valuable inputs on their export market orientation. Among the distinctive features of their export market orientation are;

- Efforts to obtain export market information comes from diverse sources. Most SMEs obtain information on export markets from their distributors, art shop owners on tourist destinations in Bali, participation in trade shows, and only a small part using information technology.

- Dissemination of information on the export market to the internal party has been good, but not good to external parties, especially the distributor.

- Responsiveness to information about the export market environment is not fast because of information that supports decision-making is not available with sufficient enough so that employers cannot take decisions quickly.

\section{Acknowledgment}

The author wishes to acknowledge all the contributors for developing and maintaining this article, especially to promotor doctoral program in management science Padjadjaran University, Prof. Dr. Yuyus Suryana, SE, M.Si. And copromotors Prof. Dr. Faisal Afiff, SE, Spec.Lic, and Dr. R. Arief Helmi, SE, M.Si.

\section{References}

[1] Singh, R., \& Garg, S., "The competitiveness of SMEs in a globalized economy observations from China and India", Management Research Review, vol. 33, no. 1, 2010, pp 54-65.

[2] Al-Hyari, K., Al-Weshah, G., \& Alnsour, M., "Barriers to internationalization in SMEs: evidence from Jordan". Marketing Intelligence \& Planning, vol. 30, no. 2, 2012, pp. 188-211.

[3] Leonidou, L., "An analysis of the barriers hindering small business export development", Journal of Small Business Management, vol. 42 no. 3, 2004, pp. 279-302.

[4] Dodd, C., "Export market orientation and performance: an analysis of Australian exporters". Conference: Marketing in International and Cross-Cultural Environments ANZMAC, 2005, pp. 28-34.

[5] Raju, P., Lonial, S. C., \& Crum, M. D., "Market orientation in the context of SMEs: a conceptual framework", Journal of Business Research, vol. 64, 2011, pp.1320-1326.

[6] Verhees, F. J., \& Meulenberg, M. T., "Market orientation, innovativeness, product innovation, and performance in small firms", Journal of Small Business Management, vol. 42, no. 2, 2004, pp. 134154.

[7] Anderson, V., \& Boocock, G., "Small firms and internationalization: learning to manage and managing to learn", Human Resource Management Journal, vol. 12, 2002, pp. 5-24.

[8] Kumar, K., "Similarities \& differences in the strategic orientation, innovation pattern and performance of SMEs and large companies", The Business Review, Cambridge, vol. 16, no.2, 2010, pp. 50-56.

[9] Murray, J., Gao, G., \& Kotabe, M., "Export market orientation and export performance: the mediating role of marketing capabilities and positional advantages", Journal of the Academy of Marketing Science, vol. 39, no. 2, 2011, pp. 252-269. 
[10] Chi, T., \& Sun, Y., "Development of firm export market oriented behavior: evidence from an emerging economy", International Business Review, vol. 22, 2013, pp. 339-350.

[11] Micheels, E. T., \& Gow, H., "The effect of alternative market orientation strategies on firm performance", International Journal of Marketing Studies, vol. 4, no. 3, 2012, pp. 2-15.

[12] Dobni, C. B., \& Luffman, G., "Determining the scope and impact of market orientation profiles on strategy implementation and performance". Strategic Management Journal, vol. 24, 2003, pp. 577585 .

[13] Cadogan, J. W., Kuivalainen, O., \& Sundqvist, S., "Export marketoriented behavior and export performance: quadratic and moderating effects under differing degrees of market dynamism and internationalization", Journal of International Marketing, vol. 17, no. 4, 2009, pp. 71-89.

[14] Narver, J. C., \& Slater, S. F., "The effect of a market orientation on business profitability", Journal of Marketing. 1990, pp. 20 - 35.

[15] Kumar, E., Jones, E., Rajkumar, V., \& Leone, R. P., "Is market orientation a source of sustainable competitive advantage or simply the cost of competing?", Journal of Marketing, vol. 75, 2011, pp.16-30.

[16] Dutta, S. K., "Market orientation ambidexterity". SCMS Journal of Indian Management. January - March, 2013, pp. 54-66.
[17] Kirca, A. H., Jayachandran, S., \& Bearden, W. O., "Market orientation: a meta-analytic review and assessment of its antecedents and impact on performance", Journal of Marketing, vol. 69, 2005, pp. 24-41.

[18] Mehra, S., \& Joyal, A., "On adopting quality orientation as an operations philosophy to improve business performance in banking services", International Journal of Quality \& Reliability Management, vol. 28, no. 9, 2011, pp. 951-968.

[19] Shoham, A., Rose, G. M., \& Kropp, F., "Market orientation and performance: a meta-analysis", Marketing intelligence \& Planning, vol. 23 , no. 5, 2005, pp. 435-454.

[20] Amalia, P., Ionut, P., \& Eugenia, J., "Market orientation: a holistic approach of the implementation process". Annals of the University of Oradea, Economic Science Series, vol. 19, no. 1, 2010, pp. 731-736.

[21] Usman, M., Ullah, I., Kayani, M. B., Haroon, F., \& Khan, M. A., "The impact of marketing mix and market orientation on export performance", Journal of Economic and Behavioral Studies, vol. 4, no. 1, January 2012, pp. 66-71.

[22] He, X., \& Wei, X., "Linking market orientation to international market selection and international performance". International Business Review, vol. 20, 2011, pp. 535-546.

[23] Badan Pusat Statistik, "Statistik Indonesia - Statistical Yearbook of Indonesia 2014", available at http://bps.go.id/website/flipping_publikasi/SI 2014/indexFlip.php 